\title{
Developing an Algebra Textbook Based on Problem Solving to Improve Student' Learning Achievement
}

\author{
Restu Lusiana ${ }^{1}$, Tri Andari ${ }^{2}$ \\ ${ }^{1,2}$ Universitas PGRI Madiun \\ ${ }^{1}$ Correspondence Address; restu.mathedu@unipma.ac.id
}

\begin{abstract}
Students' mathematics learning achievement is influenced by many factors, one of which is the learning media used. The textbook is one alternative learning media. The textbook used previously was not focused on problem-solving, so that this development research aims to produce a textbook based on problem-solving in algebra that is valid, effective, and practical. This research uses Gall \& Borg development research which is limited to seven steps namely research and information collecting, planning, developing a preliminary form of product, preliminary field testing, main product revisions, main field testing, and dissemination. This research was conducted at the Department of Mathematics Education, Universitas PGRI Madiun. Instruments and data collection used in this study were textbook validation sheets, learning outcomes tests, and student response questionnaire. The results of the research showed that the validation result of the textbook was included in the highly valid criteria $(86,74 \%)$, the test results met the criteria of classical completeness $(82,75 \%)$, and the students' response to the textbook was very high $(83,33 \%)$. Based on these results, it can be concluded that the algebra textbook based on problemsolving can be used in learning. The results of the application of an algebra textbook based on the problem-solving show an increase in student achievement with an N-Gain value of 0.32.
\end{abstract}

Keywords: Textbook, Problem Solving, Algebra, Learning Achievement

\section{INTRODUCTION}

Learning outcomes are one of the outputs of the learning process. Learning design has an impact on student learning outcomes (Kumpas-lenk, Eisenschmidt, \& Veispak, 2018; Hawes, Moss, Caswell, Seo, \& Ansari, 2019; Prast, Van de Weijer-Bergsma, Miočević, Kroesbergen, $\&$ Van Luit, 2018). Implementation of learning requires good and appropriate tools to support the achievement of results in accordance with expectations. The textbook is one tool that can support and optimize the process of learning mathematics. According to (van den Ham \& Heinze, 2018), mathematics textbooks are ascribed an important role for classroom practice and textbooks have a substantial impact on mathematics achievement in primary school. Textbook design can increase student learning motivation and can reduce student anxiety levels in learning (Turel \& Ozer Sanal, 2018). The textbook is one approach to get students directly involved in the learning process (Putwain, Symes, Nicholson, \& Becker, 2018). The textbook can influence student creativity in understanding the material being taught so that it has a positive impact on student achievement (Ismunandar \& Nurafifah, 2019).

Based on the results of preliminary observations by distributing a questionnaire to analyze the needs of students of the Mathematics Education Program at Universitas PGRI Madiun, there was obtained some information that the teaching materials used by students were still lacking. Students only use student worksheets and reference books in insufficient quantities. The books available only contain formulas, material descriptions, and exercise, therefore the ability of students to solve problems is not optimal. Also, the appearance of material that is less interesting affects students' reading interest. The results of the questionnaire showed that $67 \%$ of the total of 30 respondents had difficulty learning in understanding the concept of algebra 
material. Students tend to have difficulty in understanding the material because algebra is one of the abstract material so it requires the ability and good thinking skills in problem-solving related to reasoning and proof. This is in line with(Mcmullen \& Hoof, 2020)that states "many students still have not developed a strong understanding of the concepts of rational numbers associated with algebra".

The textbook is one of the literations that can help students understand the material (Sievert, Ham, Niedermeyer, \& Heinze, 2019;Hadar, 2017). Mathematical literacy plays an important role as one of the life skills (Sievert et al., 2019). It is a fundamental skill that is as necessary as literacy. Therefore, mathematics teaching in schools must aim to develop mathematical literacy and to enhance each students' ability to use and apply mathematical knowledge to solve real-life problems or situations (Sumirattana, Makanong, \& Thipkong, 2017). McCrory \& Stylianides (2014) state that "most of this textbook does not have a level of focus on reasoning-and-proving that would prov ide support for students' individual efforts at understanding".

Problem-solving is a basic component of school learning that has a strong formative influence on students to introduce and develop concepts (Hadar, 2017). In mathematics, solving problems represents the most effective concept to contextualization and re-contextualization of concepts, to operational and basic mathematical knowledge transfer to ensure sustainable and meaningful learning (Căprioară, 2015; Intaros, Inprasitha, \& Srisawadi, 2014). Problemsolving model is one of the learning models that can be chosen to involve students directly in and can train students to deal with various problems and find solutions to problems both individually and in groups (Ikhsan, Munzir, \& Fitria, 2017). Students must have the opportunity to build their mathematical knowledge through teacher guidance. A teacher's choice of problem situations and ways of interventions is critical to enabling students to experience 'authentic' problem solving and the choice should reflect the teacher's intention (Căprioară, 2015). The problem-solving process consists of five elements that make up its acronym, namely (1) define, (2) assess, (3) plan, (4) implement, and (5) communicate(Sumirattana et al., 2017).

The development of a textbook is one way to facilitate the achievement of learning indicators (Rahmawati, Amin, \& Lestari, 2016). So this research aims to develop a textbook based on problem-solving to improve students' mathematics learning achievement.

\section{THE RESEARCH METHODS}

The research design used in this study is research and Development (R\&D). This research uses a Gall \& Borg development research approach. According to Gall \& Borg (Sugiyono, 2015), it is stated that the $R \& D$ cycle is organized in ten steps: research and information collecting, planning, develop preliminary form of product, preliminary field testing, main product revision, main field testing, operational product revision, operating field testing, final product revision, dissemination, and distribution. In this study the steps carried out are limited to the seven steps presented in the flowchart below: 


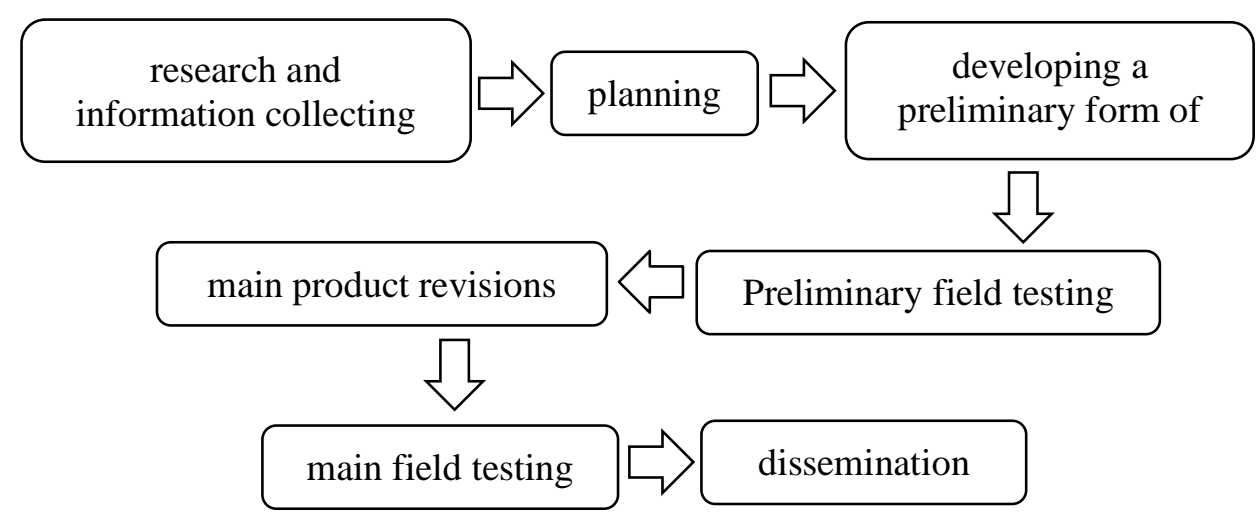

Flowchart 1. Stages of Research

The dissemination stage in this research uses a quasi-experimental research method to determine whether there is a result of "something" imposed on the subject under study by looking for the effect of certain treatments on others under controlled conditions(Krisdiana, Masfingatin, Murtafiah, \& Widodo, 2019). One group's pretest-posttest design aims to see the influence before and after being treated.

The participants in this research were students in the fifth semester of the Mathematics Education study program consisting of 2 classes. The instruments used in this study include student needs analysis questionnaire, textbook validation sheets for textbook experts and material experts, student achievement tests, and student response questionnaires.

The data analysis techniques used are as follows:

1. Results of Student Needs Analysis Questionnaire

This questionnaire was analyzed based on student answers described descriptively. The needs of students are chosen as the most dominant ones to be followed up in the development process.

2. The Results of Textbook Validation for Textbook Experts and Material Experts

Validation sheets were analyzed for each item using percentage calculation techniques on each aspect assessed by the validators. The validation qualifications are in accordance with table 1(Akbar, 2013):

Table 1. Qualification of Expert Validation Results

\begin{tabular}{cc}
\hline Range of score percentage & Qualification \\
\hline $85 \%-100 \%$ & Highly valid, can be used without improvement \\
\hline $70 \%-84 \%$ & Quite valid, can be used but needs a little improvement \\
\hline $50 \%-69 \%$ & Invalid needs major improvement \\
\hline $0 \%-49 \%$ & Invalid, cannot be used \\
\hline
\end{tabular}

\section{Learning Outcomes Test}

The test answers of student learning outcomes were analyzed by giving scores to each stage of problem-solving then added up. The stages of problem-solving include define, assess, plan, implement, and communicate. Learning is said to meet the completeness of classical learning if $75 \%$ of students meet the mastery of learning that is getting a score $\geq 75$. 


\section{Student Response Questionnaire}

Student response questionnaire sheets are sourced from (Hobri, 2010). The results obtained by each student are accumulated so that a total score is obtained. Next, the percentage of student responses is calculated. Qualifications of student response questionnaire results are according to table 2 (Arikunto, 2015).

Table 2. Qualification Results Percentage Score Questionnaire Student Response

\begin{tabular}{cc} 
Range of score percentage & Qualification \\
\hline $81 \%-100 \%$ & Very high \\
\hline $61 \%-80 \%$ & High \\
\hline $41 \%-60 \%$ & Medium \\
\hline $21 \%-40 \%$ & Low \\
\hline$<21 \%$ & Very low \\
\hline
\end{tabular}

\section{Student Pretest Posttest}

The main data used are the results of the student pretest and posttest. Data analysis techniques used a one-sample t-test (test value $=60$ ) and $\mathrm{N}$-gain. To calculate $\mathrm{N}$-Gain, use a formulaNGain $=\frac{S_{\text {post }}-S_{\text {pre }}}{S_{\text {maks }}-S_{\text {pre }}}\left(S_{\text {pre }}=\right.$ pretest score,$S_{\text {post }}=$ posttest $\quad$ scoreand $S_{\text {maks }}=$ ideal maximum score. Data analysis techniques were performed with the help of SPSS software. The $\mathrm{N}$-Gain score criteria are high ifN-Gain $>70$, average if $30 \leq \mathrm{N}$-Gain $\leq 70$, and low if $\mathrm{N}$-Gain < 30 (Situmorang, Mahibbuddin, \& Khairil, 2015).

\section{THE RESULTS OF THE RESEARCH AND THE DISCUSSION}

The information-gathering stage is carried out with a needs analysis using front-end analysis principles. Activities at this stage are carried out to establish and define development requirements (Mulyatiningsih, 2013). This stage begins by conducting interviews with colleagues, analyzing the Lesson Plan, analyzing the Algebra Structure reference book, and reviewing the literature on the Algebra Structure textbook.

a. Interview with colleagues

This stage aims to find out what problems/obstacles/phenomena are encountered in the field in connection with lectures on Algebra Structure. From the interviews, information was obtained that most of the students did not understand the prerequisite material from the Algebra Structure course, so students had difficulty understanding the concepts of the course because this course was abstract.

b. Analysis of Lesson Plan

Based on the analysis of the Lesson Plan of the Algebra Structure courses in the Mathematics Education Study Program, the material taught is too dense but lacks depth and the expected learning outcomes are not yet clear. Learning activities that occur centered on the teacher. Besides, the reference books used so far have been deemed unattractive. The learning process that is designed should involve students actively and independently. 


\section{c. Analysis of existing reference books}

At this stage, information is obtained that the presentation of the material and the presentation of the problems in the existing reference books are still not by the needs of students, examples of problems and examples of problem-solving are less structured, and in the exercise, there are no coherent stages of resolution.

\section{d. Analysis of Student Needs}

The analysis was conducted by giving a questionnaire to students. Based on the results of a questionnaire consisting of 8 questions with descriptive answers it was concluded that students need Algebra Structure textbooks that contain examples of problems and examples of solutions to problems arranged in a structured way. Also, students need practice exercises that are equipped with problem-solving guidelines according to the stages of the problem-solving model.

\section{Planning}

At the planning stage consists of planning the appearance and content. The format used in the textbook is adjusted to the principles, characteristics, and learning steps that refer to the results of the first stage. The format of the textbook content is created by presenting learning achievements, planned final competencies, and indicators of achievement before learning. The material is given by presenting the related definitions and theorems and then adding examples of questions to give students an idea of the application of the definitions and theorems that are conveyed. At the end of the chapter, there are exercises that students can do according to the problem-solving step to hone their ability to solve problems.

At this stage produces an initial draft (draft I) of the book Algebra based on Problem Solving. Textbooks made in the form of covers, learning materials, sample questions, and questions. The textbook made consisted of manuscript material to facilitate validation at the beginning.
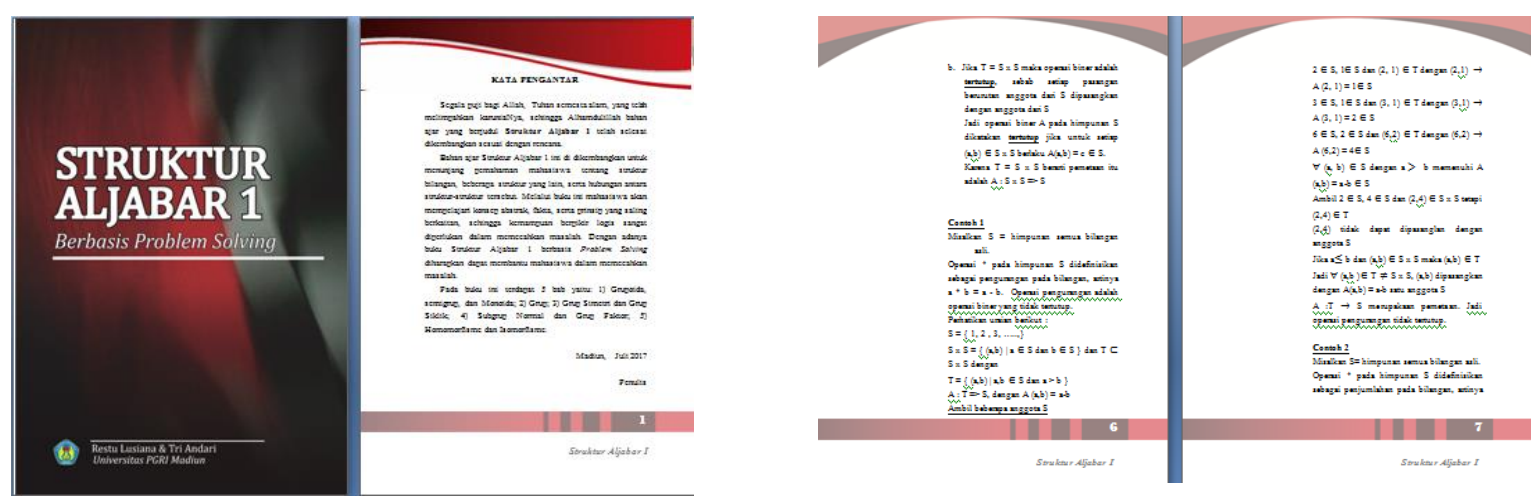

Figure 1. Preliminary Product of Textbook

After the prototype textbook is completed, the validity test is carried out by experts. Validity Test to get an assessment and advice on the appearance and content of the draft textbook that was developed. The validity test was conducted by two experts consisting of textbook experts and material experts. This validation process aims to obtain an assessment of the textbook developed, in the form of input and suggestions for the improvement and refinement of the textbook seen from various aspects related to the quality of the textbook. 
Where the quality of textbook affect student knowledge(Sievert et al., 2019). This stage begins with the use of a textbook by experts, then provides an assessment of the textbook as outlined in the textbook validation sheet. The results of expert validation are as follows:

a. Results of Data Analysis of Textbook Validation Sheets

The results of the data analysis of the textbook validation sheets obtained scores $78,36 \%$ so that it is included in the valid criteria, but some suggestions need revision to obtain valid results without revision.

b. Result of Data Analysis of Material Validation Sheet

The results of the data analysis of the material validation sheet obtained scores $78.39 \%$, so it is included in the valid criteria, but there are some suggestions so that the revision to obtain valid results without revision.

A preliminary trial was conducted to find out whether the textbook developed could be understood by students. The preliminary trial involved 6 students of class V B, these students were not from the main field testing class. The six students have different cognitive abilities.

a. Analysis of Learning Outcomes Tests

The results of student tests in solving problem-based questions and the results of data analysis of student learning outcomes in preliminary trials are as follows:

Table3. Results of Test-Based Problem Solving Stages(PFT)

\begin{tabular}{ccccccc}
\hline \multirow{2}{*}{ Subject } & \multicolumn{5}{c}{ Stages } & \multirow{2}{*}{ Score } \\
\cline { 2 - 6 } & $\mathbf{1}$ & $\mathbf{2}$ & $\mathbf{3}$ & $\mathbf{4}$ & $\mathbf{5}$ & \\
\hline S.1 & 20 & 18 & 15 & 15 & 12 & 80 \\
\hline S.2 & 18 & 15 & 12 & 12 & 10 & 67 \\
\hline S.3 & 20 & 20 & 15 & 15 & 15 & 85 \\
\hline S.4 & 20 & 18 & 15 & 12 & 12 & 78 \\
\hline S.5 & 20 & 18 & 15 & 12 & 12 & 77 \\
\hline S.6 & 18 & 15 & 15 & 12 & 12 & 75 \\
\hline
\end{tabular}

Based on the analysis of problem-based test results it appears that the ability of students to solve problems varies, this is in line with(Putranti, Charitas, \& Prahmana, 2018).

Table4. Results of Analysis Learning Outcomes (PFT)

\begin{tabular}{ll}
\hline Score $\geq 75$ & 5 students \\
\hline Score $<75$ & 1 student \\
\hline Percentage of Mastery Learning & $83,33 \%$ \\
\hline
\end{tabular}

The percentage of mastery learning is $83.33 \%$, it can be concluded that learning using Problem Solving based Algebra structure textbook has met classical completeness so that textbook can be used in main field testing.

b. Analysis of Students Response Questionnaire

The following are the scores and results of the analysis of student response questionnaire by the preliminary field testing:

Table5. Result of Analysis Students Response Questionnaire (PFT)

\begin{tabular}{lc}
\hline Obtained Total Score & 119 \\
\hline Maximum Total Score & 144 \\
\hline Percentage & $82,63 \%$ \\
\hline
\end{tabular}


Based on the table, the percentage obtained is $82.63 \%$, it can be concluded that the response to the use of textbook Algebraic Structure-based problem-solving in the preliminary field testing is included in the very high criteria.

Based on the results of the validity test of the textbook expert and the material expert, it was found that the Problem Solving based Algebra structure textbook had met the valid criteria, but there were still some shortcomings that needed to be fixed. The deficiencies in the draft I which were later corrected according to the suggestions of the validators are as follows:

a. Revision Based on Textbook Expert Advice

The revised textbook was then submitted to the expert for re-evaluation. The results of the data analysis of the revised validation textbook were $86.71 \%$ so that the textbook developed were included in the highly valid criteria. Table 3 presents a summary of the results of the validation of the textbook along with expert advice.

Table6. Summary of Data Analysis Results of Textbook Validation Sheets

\begin{tabular}{|c|c|c|}
\hline $\begin{array}{c}\text { Before } \\
(78,36 \%)\end{array}$ & Suggestions & $\begin{array}{c}\text { After } \\
(86,71 \%)\end{array}$ \\
\hline $\begin{array}{l}\text { Some sentences have multiple } \\
\text { meanings }\end{array}$ & $\begin{array}{l}\text { Sentences that have multiple } \\
\text { meanings should be corrected }\end{array}$ & $\begin{array}{l}\text { The textbook is ready } \\
\text { for use in main field } \\
\text { testing }\end{array}$ \\
\hline $\begin{array}{l}\text { There is no table of contents } \\
\text { and bibliography }\end{array}$ & $\begin{array}{l}\text { It should be completed with a } \\
\text { table of contents and bibliography }\end{array}$ & $\begin{array}{l}\text { The textbook is ready } \\
\text { for use in main field } \\
\text { testing }\end{array}$ \\
\hline $\begin{array}{l}\text { The cover does not contain } \\
\text { images related to content }\end{array}$ & $\begin{array}{l}\text { The cover should contain images } \\
\text { that relate to the contents }\end{array}$ & $\begin{array}{l}\text { The textbook is ready } \\
\text { for use in main field } \\
\text { testing }\end{array}$ \\
\hline
\end{tabular}

b. Revision Based on Material Expert Advice

The revised textbook is then submitted to the expert for re-evaluation. The results of the data analysis of the revised material validation sheet were $86.76 \%$ so that the material in the textbook developed was included in the highly valid criteria. Table 7 summarizes the results of the material validation.

Table7. Summary of Data Analysis Results of Material Validation Sheets

\begin{tabular}{lll}
\multicolumn{1}{c}{$\begin{array}{c}\text { Before } \\
(\mathbf{7 8 , 3 9 \% )}\end{array}$} & \multicolumn{1}{c}{ Suggestions } & \multicolumn{1}{c}{$\begin{array}{c}\text { After } \\
(\mathbf{8 6 , 7 6} \%)\end{array}$} \\
\hline $\begin{array}{l}\text { Indicators of achievement are } \\
\text { written at the beginning of the } \\
\text { book }\end{array}$ & $\begin{array}{l}\text { Indicators of achievement } \\
\text { should be written down in } \\
\text { each chapter to make it } \\
\text { clearer }\end{array}$ & $\begin{array}{l}\text { Each chapter is equipped } \\
\text { with learning indicators }\end{array}$ \\
\hline
\end{tabular}




\begin{tabular}{|c|c|c|c|}
\hline $\begin{array}{c}\text { Before } \\
(78,39 \%)\end{array}$ & Suggestions & \multicolumn{2}{|c|}{$\begin{array}{c}\text { After } \\
(86,76 \%)\end{array}$} \\
\hline $\begin{array}{l}\text { The completion step in the } \\
\text { example problem is not } \\
\text { structured }\end{array}$ & $\begin{array}{l}\text { Make the problem-solving } \\
\text { steps more structured }\end{array}$ & 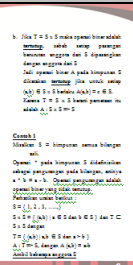 & 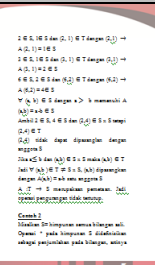 \\
\hline
\end{tabular}

Does not yet contain contextual issues
Contextual issues should be added
In the exercise section, there is no room for writing solutions
It should be given space to write solutions according to the stages of problemsolving

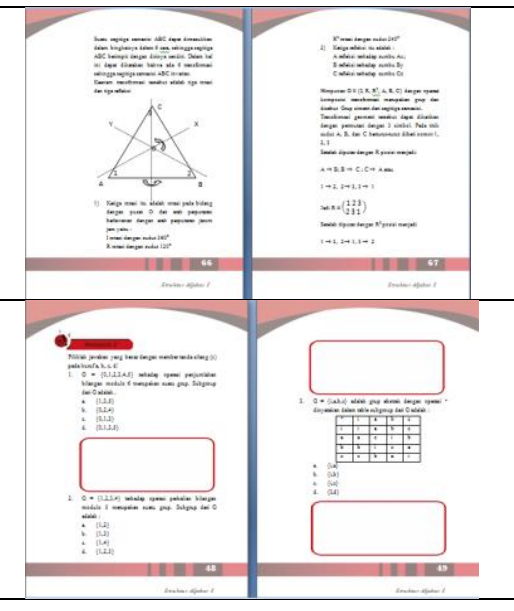

This process is carried out to obtain an evaluation of the impact of the use of the main product by students. At this stage, students conduct learning using textbooks and are given a test of learning outcomes and a questionnaire response at the end of learning. This is done to see the completeness of student learning after using the Problem Solving-based Algebra Structure teaching book. Tests and questionnaire responses were given to 29 students who took part in the main trial. The trial was conducted during 2 (two) meetings. The results of the analysis of the results of the test results of learning and response questionnaires are as follows: a. Analysis of Learning Outcomes Tests

The results of student tests in solving problems based on problems and the results of data analysis of student learning outcomes in the main field test are as follows:

Table 8. Results of Test-Based Problem Solving Stages (MFT)

\begin{tabular}{ccccccc}
\hline \multirow{2}{*}{ Subject } & \multicolumn{5}{c}{ Stages } & \multirow{2}{*}{ Score } \\
\cline { 2 - 6 } & $\mathbf{1}$ & $\mathbf{2}$ & $\mathbf{3}$ & $\mathbf{4}$ & $\mathbf{5}$ & \\
\hline S.1 & 20 & 20 & 15 & 18 & 12 & 85 \\
\hline S.2 & 18 & 15 & 15 & 15 & 12 & 75 \\
\hline S.3 & 20 & 18 & 18 & 18 & 12 & 86 \\
\hline S.4 & 20 & 20 & 15 & 15 & 15 & 85 \\
\hline S.5 & 20 & 18 & 18 & 15 & 12 & 83 \\
\hline S.6 & 20 & 18 & 15 & 18 & 12 & 83 \\
\hline S.7 & 18 & 15 & 15 & 15 & 12 & 75 \\
\hline S.8 & 20 & 18 & 18 & 15 & 12 & 83 \\
\hline S.9 & 20 & 18 & 15 & 15 & 15 & 83 \\
\hline S.10 & 20 & 18 & 15 & 15 & 12 & 80 \\
\hline
\end{tabular}




\begin{tabular}{ccccccc}
\hline Subject & \multicolumn{5}{c}{ Stages } & Score \\
\cline { 2 - 5 } S.11 & $\mathbf{1}$ & $\mathbf{2}$ & $\mathbf{3}$ & $\mathbf{4}$ & $\mathbf{5}$ & \\
\hline S.12 & 20 & 15 & 15 & 12 & 12 & 69 \\
\hline S.13 & 20 & 18 & 15 & 15 & 15 & 88 \\
\hline S.14 & 20 & 18 & 15 & 15 & 15 & 83 \\
\hline S.15 & 18 & 15 & 12 & 15 & 15 & 83 \\
\hline S.16 & 20 & 18 & 15 & 18 & 12 & 83 \\
\hline S.17 & 20 & 18 & 12 & 15 & 12 & 77 \\
\hline S.18 & 20 & 18 & 15 & 15 & 15 & 83 \\
\hline S.19 & 18 & 15 & 12 & 15 & 12 & 72 \\
\hline S.20 & 15 & 12 & 15 & 15 & 12 & 69 \\
\hline S.21 & 20 & 18 & 18 & 15 & 12 & 83 \\
\hline S.22 & 20 & 18 & 15 & 18 & 12 & 83 \\
\hline S.23 & 20 & 20 & 15 & 15 & 12 & 82 \\
\hline S.24 & 20 & 18 & 15 & 15 & 15 & 83 \\
\hline S.25 & 15 & 15 & 15 & 15 & 12 & 72 \\
\hline S.26 & 20 & 18 & 15 & 15 & 12 & 80 \\
\hline S.27 & 18 & 15 & 15 & 15 & 12 & 75 \\
\hline S.28 & 20 & 18 & 15 & 15 & 15 & 83 \\
\hline S.29 & 15 & 12 & 15 & 15 & 12 & 69 \\
\hline
\end{tabular}

Diversity of students' ability to solve problems is caused by factors such as students' ability to solve problems, mathematical representation abilities, cognitive abilities, creative thinking abilities, etc. This is in line with the results of research(Musdi \& Nari, 2019), (Syukron Maftuh, 2018), (Syukron Maftuh, 2018), (Akbarita, Eksakta, Nahdlatul, \& Blitar, 2018).

Table 9. Results of Analysis Learning Outcomes (MFT)

\begin{tabular}{lc}
\hline Score $\geq 75$ & 24 \\
\hline Score $<75$ & 5 \\
\hline Percentage of Mastery Learning & $82,75 \%$ \\
\hline
\end{tabular}

Based on the results of the main field test in class V A, 24 students have completed and 5 students who have not yet completed. It can be concluded that students who meet the mastery learning by $82.75 \%$ so that it has met the classical learning completeness criteria. The following are the scores and results of the analysis of student response questionnaire by the main field testing:

Table 10. Result of Analysis Students Response Questionnaire MFT

\begin{tabular}{lc}
\hline Obtained Total Score & 580 \\
\hline Maximum Total Score & 696 \\
\hline Percentage & $83,33 \%$ \\
\hline
\end{tabular}

Based on the results of filling out a questionnaire by 29 students in the main trial results obtained $83.33 \%$, it can be concluded that the response to the use of textbook on Problem Solving-based Algebraic Structures in the main field testing is included in the very high criteria.

This stage is carried out by applying a problem solving based algebraic textbook that meets the appropriate criteria on 62 subjects from several classes. Before the application of 
learning, students are given a pretest to see student achievement before treatment, then proceed with giving treatment that is applying problem solving-based algebra textbook, then students are given a posttest to see student achievement after treatment. Before the pretest and posttest data were analyzed, a data normality test was done using the Kolmogorov-Smirnov OneSample Test. The normality test results and the description of the pretest and posttest results in the application of the textbook are presented in Tables 11 and 12.

Tabel 11. One-Sample Kolmogorov-Smirnov Test

\begin{tabular}{llrr}
\hline & & Pretest & Posttest \\
\hline $\mathrm{N}$ & & 62 & 62 \\
\hline Normal Parametersa & Mean & 53.06 & 67.39 \\
\cline { 2 - 4 } & Std. Deviation & 10.049 & 12.313 \\
\hline Most Extreme & Absolute & .078 & .123 \\
\cline { 2 - 4 } Differences & Positive & .068 & .123 \\
\cline { 2 - 4 } & Negative & -.078 & -.091 \\
\hline Kolmogorov-Smirnov Z & .611 & .969 \\
\hline Asymp. Sig. (2-tailed) & & .850 & .304 \\
\hline
\end{tabular}

Conclusion: Distribution is Normal

Tabel 12. Descriptive Statistics

\begin{tabular}{lcccccccc}
\hline & \multicolumn{1}{c}{ N } & \multicolumn{2}{c}{ Range } & Minimum Maximum & \multicolumn{2}{c}{ Mean } & \multicolumn{2}{c}{ Std. Deviation Variance } \\
& Stat. & Stat. & Stat. & Stat. & Stat. & Std. Error & Stat. & Stat. \\
\hline Pretest & 62 & 42 & 34 & 76 & 53.06 & 1.276 & 10.049 & 100.979 \\
\hline Posttest & 62 & 43 & 48 & 91 & 67.39 & 1.564 & 12.313 & 151.618 \\
\hline N-Gain & 62 & 1 & 0 & 1 & .32 & .025 & .200 & .040 \\
\hline
\end{tabular}

The normality test in table 11 shows that the data are normally distributed, because of the sig. (2-tailed) $>0.05$. The results of the analysis of learning achievement data for 62 students showed the difference between learning achievement before (53.06) and after (67.39) using algebra textbook-based problem-solving. While the results of the $\mathrm{N}$-Gain analysis showed that the average $\mathrm{N}$-Gain statistic was 0.32 . The results of the analysis of one sample t-test are presented in table 13 .

Tabel 13. One-Sample Test

\begin{tabular}{lcccccc}
\hline & \multicolumn{8}{c}{ Test Value $=60$} \\
\cline { 1 - 3 } & & & Sig. & Mean & \multicolumn{2}{c}{$95 \%$ Confidence Interval } \\
\cline { 1 - 3 } & & df & (2-tailed) & Difference & Lower & Upper \\
\hline Pretest & -5.434 & 61 & .000 & -6.935 & -9.49 & -4.38 \\
\hline Posttest & 4.724 & 61 & .000 & 7.387 & 4.26 & 10.51 \\
\hline
\end{tabular}

Based on table 13, it was obtained that t pretest was -5.434 and the posttest was 4.724 with a significance coefficient of $0.000<0.05$, respectively. This shows that the average pretest 
and posttest are not the same as the value test. The average pretest $53.06<60$ and the average posttest 67.39> 60. It shows that learning using algebra textbook-based problem solving can improve student achievement with an $\mathrm{N}$-Gain score of 0.32 included in the average category.

The research and development process is carried out and begins with several stages including (1) conducting a preliminary study, namely gathering initial information including interviews with colleagues, analyzing the lesson plan, analyzing existing Algebra Structure reference books, and analyzing student needs. From the observations obtained an illustration that students need teaching materials in the form of a textbook that fit student characteristics. (2) planning of this activity includes the selection of the textbook format (appearance and content). (3) develop a preliminary form of the product. At this stage, a draft of the textbook Algebra Structure-based Problem Solving was made. The textbook is made in the form of covers, materials, sample questions, exercises, assignments, and evaluations. After the Algebra structure textbook complete, the validity test is conducted by experts consisting of textbook experts and material experts. Validity Test is done to get an assessment and advice from experts. The results of the data analysis of the textbook validation sheets obtained scores $78,36 \%$ so that it is included in the valid criteria and the results of the data analysis of the material validation sheet obtained scores $78.39 \%$, so it is included in the valid criteria, but there are some suggestions so that the revision to obtain valid results without revision. (4) preliminary field testing. Based on the analysis of problem-based test results it appears that the ability of students to solve problems varies, the percentage of mastery learning $83.33 \%$, it can be concluded that learning using Problem Solving based Algebra structure textbook has met classical completeness, and the percentage of student responses is $82.63 \%$, it can be concluded that the response to the use of textbook Algebraic Structure-based problem-solving in the preliminary field testing is included in the very high criteria.5)Main product revision. The revised textbook is then submitted to the expert for re-evaluation. The results of the data analysis of the revised validation textbook were $86,71 \%$ and the results of the data analysis of the revised material validation sheet were $86.76 \%$. From the judgment of the two experts, it was obtained an average of $86,74 \%$ so that the material in the textbook developed was included in the highly valid criteria.6) Main field testing. At this stage also seen the diversity of students' abilities in solving the problem, the percentage of mastery learning $82,75 \%$, it can be concluded that learning using Problem Solving based Algebra structure textbook has met classical completeness, and the percentage of student responses is $83,33 \%$, it can be concluded that the response to the use of textbook Algebraic Structure-based problem-solving in the preliminary field testing is included in the very high criteria.

The results of the pretest in this study indicate that student achievement of $53.06<60$, it shows that student achievement, especially in learning algebraic structure, is not optimal. Efforts to improve the quality of learning are associated with increasing student learning achievement (Mikheeva, Schneider, Beege, \& Rey, 2019)(Brezovszky et al., 2019). By organizing learning using problem solving-based algebra structure textbook, student learning achievement increases to 67.39> 60. If you see an average N-Gain of 0.32 included in the average criteria, then an increase in student learning achievement using problem-based structure textbook solving can be said to be quite effective, this is in line with several studies 
which state that the development of teaching materials can improve student learning achievement(Wewe \& Juliawan, 2019)(Pratama, Sudiyanto, \& Riyadi, 2019)(Kesumawati \& Octaria, 2019)(Anwar, Choirudin, Ningsih, Dewi, \& Maseleno, 2019).

\section{CONCLUSION AND SUGGESTION}

Based on the results and discussion above, showed that the validation result of the textbook was included in the highly valid criteria $(86,74 \%)$, the test results met the criteria of classical completeness $(82,75 \%)$, and the students' response to the textbook was very high $(83,33 \%)$. Based on these results, it was concluded that algebra textbooks based on problemsolving can be used in learning. The results of the application of algebra textbook based on the problem-solving show an increase in student achievement (before 53.06 and after 67.39) with an $\mathrm{N}$-Gain value of 0.32 included in the average category. Suggestions for similar studies should be carried out with a larger number of samples, involving more than 2 experts, and not limiting the stages of the study to get better results.

\section{REFERENCES}

Akbar, S. (2013). Instrumen Perangkat Pembelajaran. Bandung: Remaja Rosdakarya.

Akbarita, R., Eksakta, F. I., Nahdlatul, U., \& Blitar, U. (2018). Kemampuan Berpikir Kreatif dalam Menyelesaikan Permasalahan Geometri. JPE (Jurnal Pendidikan Edutama), 5(2), 63-68.

Anwar, M. S., Choirudin, Ningsih, E. F., Dewi, T., \& Maseleno, A. (2019). Developing an Interactive Mathematics Multimedia Learning Based on Ispring Presenter in Increasing Students' Interest in Learning Mathematics. Al-JAbar, 10(1), 135-150.

Arikunto, S. (2015). Dasar-dasar Evaluasi Pendidikan. Jakarta: Bumi Aksara.

Brezovszky, B., Mcmullen, J., Veermans, K., Hannula-, M. M., Rodríguez-aflecht, G., Pongsakdi, N., \& Laakkonen, E. (2019). Effect of a Mathematics Game-Based Learning Environment on Primary School Students' Adaptive Number Knowledge. Computers \& Education, 128, 63-74.

Căprioară, D. (2015). Problem Solving - Purpose and Means of Learning Mathematics in School. Procedia - Social and Behavioral Sciences, 191, 1859-1864.

Hadar, L. L. (2017). Studies in Educational Evaluation Opportunities to learn: Mathematics textbook and students ' achievements 认⿱乛龰. Studies in Educational Evaluation, 55(October), $153-166$.

Hawes, Z., Moss, J., Caswell, B., Seo, J., \& Ansari, D. (2019). Relations between Numerical , Spatial, and Executive Function Skills and Mathematics Achievement: A LatentVariable Approach. Cognitive Psychology, 109(December 2018), 68-90.

Hobri. (2010). Metodologi Penelitian Pengembangan (Aplikasi pada Penelitian Pendidikan Matematika). Jember: Pena Salsabila.

Ikhsan, M., Munzir, S., \& Fitria, L. (2017). Kemampuan Berpikir Kritis dan Metakognisi Siswa 


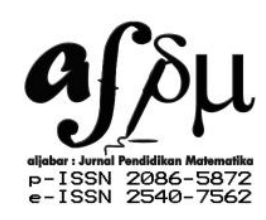

dalam Menyelesaikan masalah Matematika Melalui Pendekatan Problem Solving. Aksioma, 6(2), 234-245.

Intaros, P., Inprasitha, M., \& Srisawadi, N. (2014). Students' Problem Solving Strategies in Problem Solving - Mathematics Classroom. Procedia-Social and Behavioral Science, 116, 4119-4123.

Ismunandar, D., \& Nurafifah, L. (2019). Pengaruh Penggunaan Buku Ajar Matematika Berbantuan Geogebra terhadap Karakter Kreatif Siswa. PRISMA, 2, 526-532.

Kesumawati, N., \& Octaria, D. (2019). Developing Statistics Learning Equipment Based on the PMRI Approach Oriented to Students' Statistical Reasoning Ability. Al-Jabar, 10(1), 8799.

Krisdiana, I., Masfingatin, T., Murtafiah, W., \& Widodo, S. A. (2019). Research-based learning to increase creative thinking skill in mathematical Statistic Research-based learning to increase creative thinking skill in mathematical Statistic. Journal of Physics: Conference Series.

Kumpas-lenk, K., Eisenschmidt, E., \& Veispak, A. (2018). Studies in Educational Evaluation Does the design of learning outcomes matter from students ' perspective ?. Studies in Educational Evaluation, 59, 179-186.

McCrory, R., \& Stylianides, A. J. (2014). Reasoning-and-proving in mathematics textbook for prospective elementary teachers. International Journal of Educational Research, 64, 119-131.

Mcmullen, J., \& Hoof, J. Van. (2020). The role of rational number density knowledge in mathematical development. Learning and Instruction, 65, 101-228.

Mikheeva, M., Schneider, S., Beege, M., \& Rey, G. D. (2019). Boundary Conditions of The Politeness Effect in Online Mathematical Learning. Computers in Human Behavior, 92, 419-427.

Musdi, E., \& Nari, N. (2019). Analisis Kemampuan Representasi Matematis Siswa dalam Menyelesaikan Soal Pemecahan Masalah Matematika. Jurnal Ta'dib, 22(1).

Prast, E. J., Van de Weijer-Bergsma, E., Miočević, M., Kroesbergen, E. H., \& Van Luit, J. E. H. (2018). Relations between mathematics achievement and motivation in students of diverse achievement levels. Contemporary Educational Psychology.

Pratama, R. W., Sudiyanto, \& Riyadi. (2019). The Development Of Attention, Relevance, Confidence, And Satisfaction (ARCS) Model Based on Active Learning to Improve Students'learning Motivation. Al-Jabar, 10(1), 59-66.

Putranti, S. D., Charitas, R., \& Prahmana, I. (2018). Kemampuan siswa dalam menyelesaikan soal matematika berbasis masalah, JNPM (Jurnal Nasional Pendidikan Matematika), 2(1), 86-97.

Putwain, D. W., Symes, W., Nicholson, L. J., \& Becker, S. (2018). Achievement Goals , Behavioural Engagement, and Mathematics Achievement: A Mediational Analysis. 
Learning and Individual Differences, 68(March), 12-19.

Rahmawati, R., Amin, M., \& Lestari, U. (2016). Pengembangan Buku Ajar Biologi Sel. Jurnal Pendidikan Matematika dan Sains, 1(9), 116-121.

Sievert, H., Ham, A. Van Den, Niedermeyer, I., \& Heinze, A. (2019). Effects of Mathematics Textbook on The Development of Primary School Children's Adaptive Expertise in Arithmetic. Learning and Individual Differences, 74(June 2018), 101716.

Situmorang, R. M., Mahibbuddin, \& Khairil. (2015). Penerapan Model Pembelajaran Problem Based Learning untuk Meningkatkan Hasil Belajar Siswa pada Materi Sistem Ekskresi Manusia. Jurnal EduBio Tropika, 3(2), 87-90.

Sugiyono. (2015). Metode Penelitian dan Pengembangan Research and Development. Bandung: Alfabeta.

Sumirattana, S., Makanong, A., \& Thipkong, S. (2017). Using realistic mathematics education and the DAPIC problem-solving process to enhance secondary school students' mathematical literacy. Kasetsart Journal of Social Sciences, 38(3), 307-315.

Syukron Maftuh, M. (2018). Profil siswa sma dalam memecahkan masalah statistika berdasarkan tingkat kemampuan matematika. FIBONACCI, 4(1), 71-86.

Turel, Y. K., \& Ozer Sanal, S. (2018). The effects of an ARCS based e-book on student's achievement, motivation and anxiety. Computers and Education, 127, 130-140.

Van den Ham, A. K., \& Heinze, A. (2018). Does the textbook matter? Longitudinal effects of textbook choice on primary school students' achievement in mathematics. Studies in Educational Evaluation, 59, 133-140.

Wewe, M., \& Juliawan, I. W. (2019). Developing Mathematical Devices with Characteristics Realistic Mathematics Education. Al-Jabar, 10(1), 1-10. 